\title{
MENINGKATKAN MUTU PENDIDIKAN DI INDONESIA MELALUI SUPERVISI PENDIDIKAN
}

\author{
Oleh : Nahdah Permata Indra \\ E-mail : nahdahpermata@gmail.com
}

\begin{abstract}
ABSTRAK
Pendidikan Indonesia semakin hari kualitasnya semakin rendah. Masalah yang serius dalam meningkatkan mutu pendidikan di Indonesia adalah rendahnya mutu pendidikan di berbagai jenjang, baik pendidikan formal maupun informal. Penyebab rendahnya mutu pendidikan di Indonesia adalah masalah efektifitas, efisiensi, dan standardisasi pengajaran. Hal tersebut masih menjadi masalah pendidikan di Indonesia pada umumnya. Adapun masalah khusus dalam dunia pendidikan yaitu rendahnya sarana fisik, rendahnya kualitas guru, rendahnya kesejahteraan guru, rendahnya prestasi siswa, rendahnya kesempatan pemerataan pendidikan, rendahnya relevansi pendidikan dengan kebutuhan, dan mahalnya biaya pendidikan. Oleh karena itu, supervisi pendidikan adalah hal yang sangat penting dilakukan untuk meningkatkan mutu pendidikan di Indonesia. Kegiatan supervisi dilaksanakan melalui berbagai proses pemecahan masalah pengajaran, dan bertujuan untuk meningkatkan efektifitas dan efisiensi proses belajar mengajar, supervisi merupakan bantuan kepada guru dalam perbaikan situasi belajar mengajar, supervisi pendidikan meliputi supervisi terhadap pengajaran maupun komponen pendukungnya.
\end{abstract}

Kata Kunci : Supervisi pendidikan, mutu pendidikan

\section{PENDAHULUAN}

Supervisi pendidikan adalah hal yang sangat penting untuk dilakukan untuk meningkatkan mutu pendidikan. Mutu pendidikan sangat berkaitan erat dengan keprofesionalan guru dalam menghadapi permasalahan-permasalahan yang ada di dunia pendidikan baik pada masa saat ini 
atau masa yang akan datang. Berdasarkan hal tersebut pendidikan merupakan faktor yang penting karena pendidikan salah satu penentu mutu SDM (Sumber Daya Manusia), dimana manusia dapat membina kepribadiannya dengan jalan mengembangkan potensi-potensi yang dimiliki sesuai dengan nilai-nilai yang ada didalam masyarakat.

Supervisi dilakukan dalam rangka menjamin pembelajaran yang berkualitas. Artinya, bahwa keberhasilan pelaksanaan supervisi diukur dari peningkatan prestasi belajar siswa. Penelitian Tenriningsih (2009) menemukan bahwa "terdapat hubungan langsung yang positif dan signifikan antara kinerja guru dengan prestasi belajar siswa dan terdapat hubungan langsung yang positif dan signifikan antara prestasi belajar siswa melalui supervisi pengajaran". Artinya semakin tinggi kinerja guru, semakin tinggi prestasi belajar siswa. Karena itu, untuk menghasilkan kinerja guru yang tinggi diperlukan supervisi pengajaran yang efektif

Supervisi pendidikan, bukanlah hanya sebagai pelengkap didalam Administrasi pendidikan, akan tetapi merupakan hal yang sangat penting untuk dilaksanakan. Tidak dapat dipungkiri bahwa ada sebagian para guru yang kurang konsekuen dan kurang memenuhi pra syarat dalam pekerjaannya, serta rendahnya moral guru yang dapat mengakibatkan hilangnya kewibawaan dan kaburnya status, serta kurang terampilnya guru dalam menyampaikan pelajaran. Karena itu sangat diperlukan pengawasan dan pembinaan yang baik. Dengan kata lain bahwa supervisi sangat diperlukan.

Nasifah (Nasifah, 2015) mengatakan bahwa, supervisi adalah salah satu komponen yang mempunyai peranan penting dalam pencapaian tujuan pendidikan. Dimana dalam pelaksanaannya supervisi merupakan pelayanan, pembinaan, bimbingan serta bantuan kepada para guru agar menjadi guru atau personal yang semakin cakap sesuai dengan perkembangan ilmu pengetahuan pada umumnya dan ilmu pendidikan pada khususnya, dengan harapan agar mampu meningkatkan efektifitas proses belajar mengajar di sekolah.

Guru dalam proses belajar mengajar adalah memegang peranan yang sangat penting, sebagaimana yang diungkapkan oleh Nana Sudjana bahwa peranan guru dalam proses belajar mengajar atau proses pengajaran belum dapat digantikan oleh mesin, radio dan teknologi yang tinggi ataupun oleh komputer yang paling modern 
sekalipun. Karena memang pada guru masih memiliki unsur-unsur manusiawi yang tak dapat digantikan oleh mesin atau alat-alat lain.

Dengan melihat betapa sangat
pentingnya guru dalam proses belajar
mengajar, maka sangatlah perlu adanya
peningkatan terhadap kemampuan profesi
guru.

Melihat Peraturan Pemerintah

Nomor 19 Tahun 2005 temenjelaskan ntang standarnasional pendidikan menjelaskan bahwa pengawasan pada pendidikan formal dilakukan oleh pengawas pendidikan (39 ayat 1), sedangkan untuk pendidikan non formal dilakukan oleh pemilik satuan pendidikan (pasal 40 ayat 1). Dan pengawas sekolah itu adalah satu fungsi penting dari manajemen pendidikan yang berkaitan dengan proses pembelajaran, hal ini mencakup dari mulai aspek persiapan sampai dengan evaluasi untuk melihat, menata, dan mengawasi kualitas dari suatu proses pendidikan demi tercapainya tujuan pendidikan nasional.

Berdasarkan uraian di atas, maka permasalahan dalam tulisan ini adalah (1) Apa penyebab mutu pendidikan di Indonesia sangat memprihatinkan? (2) Bagaimana meningkatkan mutu pendidikan di Indonesia melalui supervisi pendidikan?. Tujuan dalam tulisan ini adalah (1) Untuk mengetahui penyebab mutu pendidikan di Indonesia sangat memprihatinkan. (2) untuk mengetahui apa tindakan yang dilakukan guru dan supervisor pendidikan dalam meningkatkan mutu pendidikan dan mutu pembelajaran di Indonesia. Dengan begitu peserta didik menjadi kreatif, inovatif, terampil, dan mampu berpikir kritis terhadap masalah yang dihadapinya dan memiliki karakter, kepribadian, akhlak mulia dan pengendalian diri dalam diri peserta didik.

\section{PEMBAHASAN}

Kualitas pendidikan di Indonesia sekarang ini sangat rendah dari apayang diharapkan dan tujuan dari pendidikan itu sendiri tidak sesuai. Faktor yang mempengaruhi pendidikan di Indonesia yaitu dilihat dari faktor internalnya, meliputi jajaran dunia pendidikan baik itu departemen pendidikan nasional, dinas pendidikan daerah, dan juga sekolah yang berada di garis depan. Kemudian untuk faktor eksternalnya, adalah masyarakat pada umumnya. Dimana, masyarakat merupakan ikon pendidikan dan merupakan tujuan dari adanya pendidikan yaitu sebagai objek dari pendidikan. 
Faktor-faktor lain yang menyebabkan kualitas pendidikan di Indonesia semakin memprihatinkan yaitu :

1) Rendahnya kualitas saran fisik Misalnya banyak sekali sekolah dan perguruan tinggi kita yang gedungnya rusak, kepemilikan dan penggunaan media belajar rendah, buku perpustakaan tidak lengkap, laboratorium tidak standar, pemakaian teknologi informasi tidak memadai dan sebagainya.

2) Rendahnya kualitas guru

Kebanyakan guru belum memiliki profesionalisme yang memadai untuk menjalankan tugasnya sebagaimana disebut dalam pasal 39 UU No 20/2003.

3) Rendahnya kesejahteraan guru Dengan pendapatan yang rendah, terang saja banyak guru terpaksa melakukan pekerjaan sampingan. Ada yang mengajar lagi di sekolah lain, memberi les pada sore hari dan sebagainya

4) Rendahnya prestasi siswa

Dengan keadaan yang diatas, pencapaian prestasi siswa pun menjadi tidak memuaskan. Sebagai misal pencapaian prestasi fisika dan matematika siswa Indonesia di dunia Internasional sangat rendah.
5) Kurangnya pemerataan kesempatan pendidikan

Kesempatan memperoleh pendidikan masih terbatas pada tingkat sekolah dasar.

6) Rendahnya relevansi pendidikan dengan kebutuhan

Adanya ketidakserasian antara hasil pendidikan dan kebutuhan dunia kerja ini disebabkan kurikulum yang materinya kurang funsional terhadap keterampilan yang dibutuhkan ketika peserta didik memasuki dunia kerja.

7) Mahalnya biaya pendidikan

Pendidikan bermutu itu mahal. Kalimat ini sering muncul untuk menjustifikasi mahanya biaya yang harus dikeluarkan masyarakat untuk mengenyam bangku pendidikan. Mahalnya biaya pendidikan membuat masyarakat miskin tidak memiliki pilihan lain kecuali tidak bersekolah.

Pembinaan terhadap guru merupakan kegiatan penting dalam upaya peningkatan kualitas pendidikan pada umumnya dan secara khusus untuk peningkatan kualitas pembelajaran. Kepala sekolah sebagai memiliki tugas membina dan membimbing para guru terutama membina dan menumbuhkan profesionalitas guru. Pelaksanaan supervisi akademik yang 
dilakukan oleh kepala sekolah merupakan kegiatan pembinaan yang dapat mempercepat proses peningkatan kompetensi para guru dalam mengelola pembelajaran di kelas.

Kepala sekolah sebagai supervisor harus mampu membina para guru agar peka dan peduli terhadap perubahan serta berusaha untuk bersikap inovatif dan selalu mengembangkan kualitas sumber daya dalam mengajar dan mendidik. Peran utama kepala sekolah sebagai seorang supervisor dalam melaksanakan proses pembelajaran melalui pelaksanaan fungsi supervisi dalam bentuk penelitian, penilaian, perbaikan, dan peningkatan sehingga kualitas pembelajaran menjadi lebih baik teknik supervisi akademik yang erat berkaitan dengan pembelajaran di kelas adalah teknik kunjungan kelas, dimana teknik kunjungan kelas ini paling mudah dan sering dilakukan oleh kepala sekolah pada saat melakukan kegiatan supervisi akademik terhadap para guru. Penerapan prinsip dan fungsi teknik kunjungan kelas mudah dilakukan oleh kepala sekolah karena tujuannya adalah untuk memperoleh data mengenai keadaan sebenarnya selama guru terlibat dalam proses pembelajaran pembelajaran di kelas.
Bagi guru kunjungan kelas yang dilakukan kepala sekolah dapat menjadi motivasi tersendiri untuk memacu dirinya dalam meningkatkan kompetensi pedagogi dan profesional yaitu meningkatkan kualitas pembelajaran di kelas yang berdampak pada peningkatan kualitas pendidikan di sekolah.

Sabandi (Sabandi, 2013) mengatakan bahwa supervisor memegang peranan penting dalam meningkatkan kualitas guru agar dapat melaksanakan pembelajaran yang lebih berkualitas dan bermakna. Dengan begitu, peserta didik juga akan memberikan prestasi yang baik di bidang akademik dan non akademik.

Untuk meningkatkan kualitas pembelajaran atau menciptakan suasana pembelajaran yang inspiratif, interaktif, dan menyenangkan, guru harus mampu menggunakan teknik pembelajaran, metode pembelajaran, strategi pembelajaran, pendekatan pembelajaran, dan model pembelajaran yang tepat dalam proses pembelajaran. Guru harus mampu memotivasi dan menstimulus peserta didik untuk aktif mengemukakan pendapat dan ide-ide yang dimilikinya dalam proses pembelajaran

Guru sebagai pendidik tidak hanya berkenaan dengan penyampaian ilmu 
pengetahuan tetapi juga menyangkut pengembangan kepribadian dan pembentukan nilai-nilai etika dan estetika peserta didik dalam menghadapi tantangan hidup bermasyarakat. Tidak hanya guru yang memiliki tanggung jawab terhadap pendidikn melainkan juga supervisor.

Supervisor berusaha mengadakan preventif agar guru melakukan apa yang semestiya. Supervisor memberikan bantuan teknis dan bimbingan kepada guru agar mampu meningkatkan kualitas kerjanya, terutama melaksanakan proses pembelajaran. Supervisor membantu guru agar dapat melakukan kerja yang lebih baik, terarah dan sebagaimana mestinya.

Jadi, guru dan supervisor pendidikan memiliki peranan yang sangat penting dalam meningkatkan mutu pendidikan dan mutu pembelajaran di Indonesia.

\section{KESIMPULAN}

$$
\begin{aligned}
& \text { Berdasarkan uraian diatas dapat } \\
& \text { disimpulkan bahwa penyebab mutu } \\
& \text { pendidikan di Indonesia sangat } \\
& \text { memprihatinkan adalah rendahnya sarana } \\
& \text { fisik, rendahnya kualitas guru, rendahnya } \\
& \text { kesejahteraan guru, rendahnya prestasi } \\
& \text { siswa, rendahnya kesempatan pemerataan } \\
& \text { pendidikan, rendahnya relevansi pendidikan }
\end{aligned}
$$

dengan kebutuhan, dan mahalnya biaya pendidikan.

Dalam meningkatkan mutu pendidikan dan mutu pembelajran di Indonesia guru dan supervisor pendidikan memiliki peranan yang sangat didalamnya. Guru dan supervisor harus mampu bekerja sama dalam meningkatkan mutu pendidikan dan mengembangkan kualitas pembalajaran. Dengan terciptanya suasana pembelajaran yang kondusif untuk belajar, siswa akan merasa senang dan nyaman sehingga peserta didik menjadi kreatif, inovatif, terampil, dan mampu berpikir kritis terhadap masalah yang dihadapinya serta memiliki karakter, kepribadian, akhlak mulia dan pengendalian diri dalam diri peserta didik.

\section{REFERENSI}

Nasifah, S. L. (2015). Peranan Supervisi

Pendidikan dalam Meningkatkan

Profesionalisme Guru Pendidikan Agama

Islam di SMA Negeri Se-Salatiga. Institut Agama Islam Negeri (IAIN) Salatiga.

Sabandi, A. (2013). Supervisi Pendidikan Untuk Pengembangan Profesionalitas Guru Berkelanjutan. Jurnal Ilmiah Ilmu Pendidikan, XIII(2), 1-9. 